\title{
Islamismen udfordrer verdens orden
}

\section{Mehdi Mozaffari}

På trods af islamismens relativt store kapabilitet på den internationale arena, lider den af alvorlige svagheder. Den vigtigste svaghed er måske, at den udspringer fra et område, som stadig ikke er industrialiseret eller veludviklet

Islamisme er ikke nogen egentlig religion. Islamisme er en religiøs ideologi. Islamismen er en skuffelsens ideologi, en nostalgisk, nærmest revanchistisk bevægelse, som ønsker at genetablere islams storhed efter århundreder med forfald og stagnation. Og dette bør være udgangspunktet for både at få en tilstrækkelig forståelse af islamismen og at vurdere dens indflydelse på den internationale arena.

En af metoderne at vurdere en aktørs indflydelse i international politik på er at 'måle' aktørens reelle evne til at opretholde den eksisterende verdensorden og aktørens bidrag til at forbedre den. Det forholder sig på samme måde med aktørens reelle evne til at modsætte sig den eksisterende verdensorden og/ eller at forstyrre verdensordenen, så meget den kan. I denne sammenhæng fremstår islamismen som et relevant eksempel på en aktør med en temmelig forstyrrende eller chikanerende kapacitet (capacity for harassment). Islamismen udfordrer den eksisterende verdensorden både voldeligt og værdimæssigt. Desuden kæmper en betydelig del af verden mere eller mindre imod islamismen. Bekæmpelsen af islamismen begrænser sig ikke til USA eller alene til den vestlige halvkugle. Den islamiske verden har med sine 1,5 milliarder indbyggere også alvorlige problemer med islamisme.

FN, der repræsenterer både demokratiske og ikke-demokratiske stater, muslimske og ikke-muslimske lande, anser en lang række bevægel- 
ser og organisationer, som hævder at være muslimske, for at være terrororganisationer, og de står på FN's sorte liste. I flere år har FN's Sikkerhedsråd haft et problematisk forhold til det islamistiske Iran i atomspørgsmålet.

Den mest praktiske måde at få en tilstrækkelig idé om islamismens verdensanskuelse på er at sammenligne islamismens og marxismens generelle træk.

\section{Islamismens verdensanskuelse}

Islamisme er i lighed med marxisme en 'revisionistisk' og 'revolutionær' teori. Hverken marxisme eller islamisme anerkender 'staten' eller 'nationen' som 'enheder' i internationale forhold. For marxismen er 'klasserne' udgangspunkt for enhver gyldig klassificering af aktører. Ud fra dette statsløse og a-nationale synspunkt forkastes 'internationale forhold' som disciplin og begreb af både marxisme og islamisme.

Ifølge marxismen kan verden groft sagt opdeles i kapitalister, borgerskab og proletariat. Islamismen, der er udstyret med en manikæisk vision, tror på eksistensen af to slags kræfter. Dem, der tror på Allah (og ingen anden gud) og er villige til at give deres liv for virkeligg ørelsen af Allahs projekt, og de kræfter, der arbejder imod dette projekt.

I denne optik er verden delt mellem Mu'minûn (rettroende), Muslimûn (formelt troende), Ahl al-Kitâb (jøder, kristne, sabæere og zarathustrianere), Munâfiqûn (hyklere) og Kâfirûn (vantro). Mens Marx og Engels opfordrer verdens proletarer til at forene sig, opfordrer islamismen verdens sande muslimer og alle $\mathrm{Mu}$ staz'afûn (undertrykte) i almindelighed til at forene sig imod undertrykkerne. Den eksisterende verdensorden er efter deres opfattelse undertrykkende og uretfærdig.

For marxismen er den eksisterende verdensorden uretfærdig, fordi den er baseret på akkumulering af kapital, udbytning og undertrykkelse af det arbejdende folk. På dette punkt mødes islamismen med marxismen og føjer derud over en kulturel og religiøs dimension til undertrykkelsen.

Mens Lenin, hvis argument hovedsageligt tog udgangspunkt i John A. Hobsons teori (1902), betragtede imperialismen som kapitalismens højeste udviklingstrin og som sådan årsag til krig og konflikt, anser islamismen 'jøderne og korsridderne' (sammen med deres allierede) som ansvarlige for verdens elendighed i almindelighed og for muslimernes elendighed i særdeleshed. Islamismen fordømmer derfor stærkt 'jødernes og korsriddernes' sammensværgelse og deres illegitime dominans. Da de ikke tilkender det 'internationale system' nogen legitimitet, har marxismen og islamismen hverken formuleret en teori for internationalt samarbejde eller et redskab til kompromis og tilpasning. I 
praksis kan det se anderledes ud, som det var tilfældet med Nikita Khrusjtjovs 'fredelige sameksistens'.

Islamismens revisionistiske karakter førte til en anti-imperialistisk imperialisme. Den islamistiske kamp imod imperialismen er ikke en kamp om principper; målet er ikke at sætte en stopper for imperialismen som skadeligt begreb og som fejlagtig politisk og økonomisk konstruktion. Det, sagen egentlig drejer sig om for islamisterne, er at erstatte den vestlige imperialisme med et nyt islamisk overherredømme som et minde om den islamiske verdensmagts gyldne tidsalder (ét samlet verdenssamfund).

Denne linje har affødt en besynderlig politisk alliance mellem alle former for ekstremister, så længe de bare kæmper imod det nuværende internationale system. Fx er det iranske styre både allieret med den yderste venstrefløj og den yderste højrefløj rundt om i verden - med Hugo Chavez og Ku Klux Klan på én gang.

\section{Islamismens styrke og svaghed}

Det mest dominerende aspekt ved islamismens farlighed er naturligvis terrorisme i forskellige former og $\mathrm{i}$ forskelligt omfang. Fra angreb på en bus, en undergrundsbane eller en skole til det famøse angreb imod New York, Washington D.C. og Virginia den 11. september 2001. Denne begivenhed blev årsagen til kri- gen i Afghanistan (og i Pakistan), som fulgtes af invasionen af Irak, selvom landet ikke havde noget at gøre med terrorisme som sådan.

Dertil kommer atomtruslen, dels pga. den sociale og politiske ustabilitet i Pakistan og frygten for, at islamisterne får atomvåben, og dels pga. det islamistiske regime i Iran, som efter alt at dømme er på vej til at udvikle atomvåben. Dette kunne resultere i et våbenkapløb i regionen og ikke mindst føre til ayatollahstyrets dominans over regionen, hvor der findes en betydelig del af verdens naturressourcer.

De to ovennævnte elementer er det, man kan kalde den fysiske trussel. Der findes også en anden slags trussel, som vedrører demokratiske værdier, og som man kan kalde islamismens bløde aspekt eller soft power. Det er det, der især i Europa går under navnet shariafisering. Debatten om hijab, burka, halalmad og minareter er velkendte og indikerer, at nogle islamistiske grupperinger bestræber sig på at gennemføre en gradvis islamisering af vestlige samfund.

Islamismen har derfor en vis kapabilitet til at forstyrre den herskende verdensorden, fremprovokere krige og kriser, begå terroraktioner, som det koster en formue og meget mandskab at bekæmpe. Islamisterne har også fået en indirekte indflydelse i forbindelse med ændring af en række love og normer i de demokratiske samfund, som netop pga. terro- 


\section{TEMA: RELIGION I INTERNATIONAL POLITIK}

rismen og sikkerheden for deres lande og borgere har vedtaget love, som etablerer betydeligt mere kontrol med borgerne.

På trods af islamismens relativt store kapabilitet på den internationale arena, lider den af nogle alvorlige svagheder.

Den vigtigste svaghed ved islamismen er måske, at den udspringer fra et område, som stadig ikke er industrialiseret eller veludviklet. Den islamiske verden - fra Bali til Mali - er, ifølge FN's rapporter, konfronteret med en række strukturelle problemer, fx analfabetisme, stor fattigdom, undertrykkelse af kvinder og børn, korruption, lav produktivitet og stor ulighed. Det betyder altså, at til forskel fra Nazityskland og Sovjetunionen, som var industrialiserede og udrustet med temmelig veluddannet arbejdskraft og en slags politisk kultur, som gjorde dem i stand til at være selvforsynende på mange områder, heriblandt våbenindustrien, er de muslimske lande dybt afhængige af andre lande på mange substantielle områder.

Den eneste faktuelle ressource er råvarer, især olie, som næppe kan bruges systematisk som våben på det internationale marked. Disse faktorer $g ø r$, at islamismen endnu ikke er i stand til at true den eksisterende verdensorden i samme grad, som Nazityskland og Sovjetunionen gjorde i sin tid. Man kunne tænke sig, at det netop er islamisternes bevidsthed om deres dybe afhængighed, som er årsagen til, at nogle af dem forsøger at få fat på atomvåben som substitut for klassiske våben.

Dernæst er islamismens svaghed et resultat af dens splittelse.

Islamismen er en monistisk enhed, men langt fra en monolitisk bevægelse. Til trods for de globale forhåbninger blandt deres ideologer har islamisterne ikke noget centrum, og der findes ikke nogen overordnet pan-islamisk, radikal ledelse.

For overskuelighedens skyld er det hensigtsmæssigt at opsummere opdelingen inden for islamismens univers omkring to centrale søjler: En opdeling, der er bestemt af tilknytningen til religiøs underopdeling, og en opdeling, der udspringer af de mange forskelligartede krav og ambitioner.

\section{Sunni, shia og wahhabi}

Inden for den religiøse underopdeling er islamismen delt i tre hovedgrene: sunni, shia og wahhabi. Denne klassificering er hverken perfekt eller udtømmende, men den er praktisk. Fx er wahhabi også en sunni-undersekt. Men den er så forskellig fra andre sunni-undersekter, at den kan behandles som en selvstændig enhed. Sunnisme er opdelt i fire teologiske og juridiske skoler: Hanafi, Mâleki, Shâfíi og Hanbali. Wahhabi er en afledning af Hanbali-skolen med en særlig dogmatisk fortolkning af islam.

Sunni-islamisterne udgør det sto- 
re flertal blandt islamister. Sunni-bevægelserne spænder over et geografisk område, der går fra Mali til Bali, fra den somaliske ørken til den pakistanske del af Himalaya. Rent kronologisk er sunni-islamisme ældre end både shia- og wahhabi-islamisme. Dens rødder kan spores tilbage til Ibn Hanbal (780-855) og derfra til teologen al-Ghazali (1058-1111).

Som fænomen stammer vore dages islamisme som bevægelse og organisation fra det 20. århundrede. Den opstod samtidig med, at Hassan al-Banna skabte Det Muslimske Broderskab i Egypten i 1928. Det Muslimske Broderskab er modersammenslutning for underorganisationer som Tanzim al-jihad (Jihad Organisation) eller Al-Takfir val-Hijra (Soning og hellig flugt). Sidstnæunte var ansvarlig for mordet på præsident Anwar al-Sadat i 1981. Folk som Ayman al-Zawahiri, Osama bin Ladens næstkommanderende, kommer fra denne type organisation.

Wahhabi-grenen af islamismen findes især i Saudi-Arabien, i mindre udstrækning i de forskellige emirater ved den Persiske Golf og endelig i visse dele af Kaukasus (især i Tjetjenien) og Centralasien. Wahhabi-islamisme har rod i Muhammad 'Abd al-Wahhabs lære (1703-1792), som var meget påvirket af Ibn Taymiyya (1268-1328), en Hanbali-teolog fra middelalderen.

Sammenlignet med andre muslimske sekter er wahhabierne almindeligt kendt for at være særligt rigo- ristiske og til tider voldelige. Hidtil usete, globale og spektakulære terrorhandlinger som angrebene den 11. september er blevet et varemærke for wahhabi-islamismen. Den udøver også brutalitet i muslimske lande som fx i forbindelse med mordet på og halshugningen af gidsler $\mathrm{i}$ Irak begået af al-Zarqawis brigader. For øjeblikket er grænserne mellem wahhabier og ikke-wahhabier slørede, og de sekteriske skel er praktisk talt forsvundet. Blandt sine tropper regner al-Qaeda fx en række sunnimuslimer med forskelligt sekterisk og teologisk tilhørsforhold. Ledende al-Qaeda-personligheder som alZarqawi (dræbt i Irak juni 2006) og især Ayman al-Zawahiri er sunnier, men ikke wahhabi-muslimer. Dette vidner om organisationens trans-sekteriske karakter; den er ved at udvikle sig til en økumenisk, global terrororganisation.

Shia-islamismen repræsenteres først og fremmest af det post-revolutionære Iran, et land, hvor omkring 80 pct. af befolkningen er tilknyttet shia-islam. Som resultat af den islamiske revolution i 1979 blev Iran et aktivt centrum for terroraktiviteter i islams navn. Den første begivenhed var gidselaffæren den 4 . november 1979, hvor 55 amerikanske diplomater og medarbejdere fra den amerikanske ambassade i Teheran blev holdt fanget i 444 dage. Den shia-islamistiske gruppe Hizbollah fra Libanon blev oprettet i regi af Den Islamiske Republik Iran i 1982 som re- 
aktion på den israelske besættelse af Sydlibanon. I flere år udførte organisationen voldelige aktioner mod militærpersoner og civile i Israel under påskud af at være et legitimt forsvar mod besætteren. Hizbollah er nu repræsenteret i både det libanesiske parlament og i regeringen.

Historisk set har forholdet mellem sunni og shia generelt været konfliktfyldt, og konfliktniveauet har varieret afhængig af politisk kontekst.

Det er således ingen overdrivelse at sige, at der, til trods for vigtige forskelle og endog gensidigt fjendskab blandt sunni-, shia- og wahhabiislamister, er mere, der forener dem end skiller dem. De tror på islams totalitære karakter, og de stræber efter det samme endemål (en verdensomspændende Umma). Desuden nærer de stærke antivestlige følelser, og de bruger voldelige aktionsformer. De deler det samme ideal, benytter de samme metoder og udviser det samme mønster med hensyn til venskab og fjendskab i forhold til den ydre verden. Alle disse elementer tyder på, at der findes en stiltiende strategisk alliance mellem disse tre sekteriske grene inden for islamismen.

\section{National og global islamisme}

Det andet kriterium for at differentiere den ene islamistiske gruppe fra den anden er rækkevidden for deres mål. Dette kriterium giver os mulighed for at identificere to kategorier af islamister: de 'nationale islamister' og de 'globale islamister'. Begge grupper deler den samme ideologi, men rækkevidden for deres mål er ikke ens.

National islamisme: Der findes bevægelser, hvis krav til dels kommer til udtryk gennem det moderne begreb 'nation', især i fire geografiske områder: Kashmir, Palæstina, Libanon og Tjetjenien. Hvert områdes geografiske kontekst afføder forskellig brug af nationalisme fra disse islamistiske grupper. Lashkar-e-Tayyiba [Den Rene Hær] ønsker, at Kashmir skal løsrives fra Indien og integreres i Pakistan. Formålet for de islamiske regimenter, der kæmper i Tjetjenien, er at løsrive Tjetjenien fra Rusland og danne en selvstændig stat. Hamas kræver uafhængighed for Palæstina, men insisterer også på udslettelsen af en allerede eksisterende nation, Israel. Selv om Hizbollah støtter ideen om at udslette Israel, koncentrerer den sig for øjeblikket om at udvide sin politiske og militære dominans inden for en allerede eksisterende stat: Libanon.

Global islamisme spænder over bevægelser som Det Muslimske Broderskab i dets forskellige afskygninger, Khomeini-inspirerede bevægelser i Iran, tilhængere af Mawdudi i Pakistan og andre steder og naturligvis organisationen al-Qaeda. De forfølger alle det samme mål, skønt i forskelligt tempo og gennem forskellige diskurser. Deres mål er kort sagt genoprettelsen af islams magt 
og ære, og dette er opnået, når alle muslimske områder er blevet befriet fra de ikke-muslimske besætteres åg. De globale islamisters diskurs har en konsistent og selvforstærkende karakter, som kan spores i skrifterne fra denne doktrins mest indflydelsesrige ledere. Hasan al-Banna (1906-1949) var den første, der udtalte sig om sit program for at nå dette mål. Han sagde:

"Hvis islam igen skal spille rollen som leder af menneskeheden, er det nødvendigt, at det muslimske samfund bliver genskabt i sin oprindelige form. Det er nødvendigt at genoplive det muslimske samfund, der er begravet under ruinerne af flere generationers menneskeskabte traditioner, og som er knust under vægten af de falske love og skikke, der end ikke er fjernt beslægtede med den islamiske lære, og som til trods herfor kalder sig selv 'islams verden'".

Sayyid Qutb (1906-1966) var den anden islamistiske tænker og leder, der tydeligt gav udtryk for brugen af jihad for at nå det endelige mål: erobringen af verden. Qutb udtrykker det meget kraftfuldt:

"Forsvaret er dog ikke det endelige mål for den islamiske jihadbevægelse, men et middel til at oprette den Guddommelige Myndighed i den, så den bliver hovedkvarter for islams bevægelse, som derefter bliver ført rundt i hele verden til hele menneskeheden, eftersom genstanden for denne religion er hele men- neskeheden og dens aktivitetssfære er hele verden".

Den pakistanske teolog Mawdudi (1903-1979) forklarer i sit værk Islam Today, hvordan succes kan opnås ved at følge Muhammeds eksempel. I kapitlet 'The real cause of success', skildrer Mawdudi, hvordan de første muslimer var en 'lille, men hengiven gruppe af modige og uselviske mennesker', som det lykkedes at skabe en bystat, hvor de islamiske principper 'ikke længere blot var teoretiske udtalelser, men blev en levende realitet i det personlige og sociale liv'. Medina-modellen er den 'ideelle periode', som Mawdudi kaldte et af sine kapitler. Ud fra denne model forklarer Mawdudi, hvordan islam bredte sig ud i verden med midler, der omfattede brug af vold. For Mawdudi skal Muhammeds og hans umiddelbare efterfølgeres erfaringer tjene som model for muslimer i dag.

Til trods for at Ayatollah Khomeini (1902-1989) repræsenterede shiamindretallet, som har været offer for sunni-kalifatet gennem historien, var han overbevist om nødvendigheden af en verdensomspændende islamisk magt. Han sagde:

"Dette er en pligt, som alle muslimer skal efterkomme, i alle muslimske lande, for at opnå islams triumferende politiske revolution. Vi ser også, at imperialisterne og de tyranniske, egoistiske herskere sammen har delt det islamiske hjemland. De har skilt de forskellige segmenter af 


\section{TEMA: RELIGION I INTERNATIONAL POLITIK}

den islamiske umma fra hinanden og har oprettet kunstigt adskilte nationer".

\section{Zawahiris plan}

Sidst, men ikke mindst udtrykkes der i et af de vigtigste breve fra $\mathrm{Za}$ wahiri til Zarqawi meget klart brevskriverens intentioner med hensyn til verdens fremtid.

I dette brev, der blev opsnappet af amerikanerne 13. oktober 2005, hedder det: "Det har altid været min overbevisning, at islams sejr aldrig vil finde sted, før der er etableret en muslimsk stat efter Profetens forbillede i hjertet af den islamiske verden, nærmere bestemt i Levanten, Ægypten.” For at virkeliggøre denne plan opstiller Zawahiri følgende plan i fire etaper:

For det første: Fordriv de amerikanske tropper fra Irak. For det andet: Opret et kalifat over så meget af Irak som muligt. For det tredje: Udvid jihad til de sekulære nabolande, især med henblik på Egypten og Levanten - et udtryk, der beskriver Syrien og Libanon. Og endelig: Krig mod Israel.

I denne erklæring skitserer bin Ladens næstkommanderende de omfattende planer for al-Qaeda-bevægelsen. Desuden skrev Zawahiri i en bog, der blev smuglet ud af Afghanistan i december 2001, at målet med jihad er at oprette en religiøs stat i hele den islamiske verden og 'genindsætte det faldne kalifat og genvinde den tabte magt og ære'.

Islamisme er et nyt fænomen som international aktør. Den har forskellige ansigter og mangfoldige dimensioner. Den kan være blød og kompromissøgende, og den kan være hård og brutal. Den kan proklamere at være 'ikke-voldelig', og den kan dekretere jihad.

Den kan også være en ikke-statslig aktør, en paraplyorganisation (alQaeda), et parti (Hizb ut-Tahrir eller Det Muslimske Broderskab) eller semi-statslig som Taleban og en regulær stat som Den Islamiske Republik Iran.

Bag det multiforme fænomen står én ting fast: at islamismen - som ideologi, som organisation og ikke mindst som stat - udfordrer den eksisterende verdensorden og placerer sig selv som prætendent til verdensherredømmet. Det er måske ren utopi. Men historisk erfaring vidner om, at den slags utopier kan være farlige både for verden og især for utopimagerne!

Mehdi Mozaffari er professor på Institut for Statskundskab, Aarhus Universitet og leder af Center for Forskning $i$ Islamisme og Radikaliseringsprocesser (CIR) samme sted. 